\title{
Human Prescription Drug Distribution
}

National Cancer Institute

\section{Source}

National Cancer Institute. Human Prescription Drug Distribution. NCI Thesaurus. Code C111077.

The process of distributing prescription medications for human use. 